\title{
Unexpected Ethyltellurenylation of Epoxides with Elemental Tellurium under Lithium Triethylborohydride Conditions
}

\author{
Damiano Tanini *(1) and Antonella Capperucci \\ Department of Chemistry “Ugo Schiff”, Università di Firenze, Via della Lastruccia 3-13, 50019 Sesto Fiorentino, \\ Italy; antonella.capperucci@unifi.it \\ * Correspondence: damiano.tanini@unifi.it; Tel.: +39-055-4573552
}

Received: 26 May 2020; Accepted: 15 June 2020; Published: 6 July 2020

check for updates

\begin{abstract}
The one-pot multistep ethyltellurenylation reaction of epoxides with elemental tellurium and lithium triethylborohydride is described. The reaction mechanism was experimentally investigated. Dilithium ditelluride and triethyl borane, formed from elemental tellurium and lithium triethylborohydride, were shown to be the key species involved in the reaction mechanism. Epoxides undergo ring-opening reaction with dilithium ditelluride to afford $\beta$-hydroxy ditellurides, which are sequentially converted into the corresponding $\beta$-hydroxy-alkyl ethyl tellurides by transmetalation with triethyl borane, reasonably proceeding through the $\mathrm{S}_{\mathrm{H}} 2$ mechanism.
\end{abstract}

Keywords: tellurium; tellurides; ditellurides; superhydride; boranes; ring-opening-reactions; epoxides; transmetalation; radicals

\section{Introduction}

Organoselenium [1,2] and organotellurium [3] compounds continue to find wide application in chemical sciences and biology [4-8]. Tellurium-containing derivatives play an important role in organic synthesis [3,9], materials science [10,11], and medicinal chemistry [8,12-15]. The incorporation of tellurium atoms into organic structures is often a rewarding strategy in developing new enzyme modulators [14-17], catalysts [18], smart materials [10,11], and glutathione-peroxidase-like antioxidants [19-25]. Additionally, often undergoing regio- and stereo-selective transformations, organotellurium compounds can be employed in synthetically useful functional group conversion reactions [26,27] and carbon-carbon bond-forming processes [28-31]. Owing to these features, tellurenylation reactions provide an attractive functional handle for further elaboration. Selected examples of biological and synthetic applications of organotellurium compounds are presented in the Figure 1.

The development of new, reliable, and general methodologies towards these chalcogen-containing organic molecules is thus highly sought after in organic synthesis. Particularly, the possibility to access densely functionalised and $\mathrm{sp}^{3}$-rich compounds, characterised by high molecular complexity, enables the possibility to define and explore new chemical space and plays a key role in terms of successfully developing new catalysts and drug candidates $[32,33]$. Furthermore, $\mathrm{sp}^{3}$-rich organochalcogens bearing $\mathrm{O}$ - and $\mathrm{N}$-containing functionalities have been demonstrated to possess improved catalytic and pharmacological properties [15-17,20,23,34]. However, although a number of methods for the synthesis of selenides and tellurides have been reported, a number of limitations remain, including functional-group compatibility and the harsh reaction conditions. Therefore, the development of mild procedures for the synthesis of densely functionalised molecules still remains challenging. 
a. Applications of organotellurium compounds

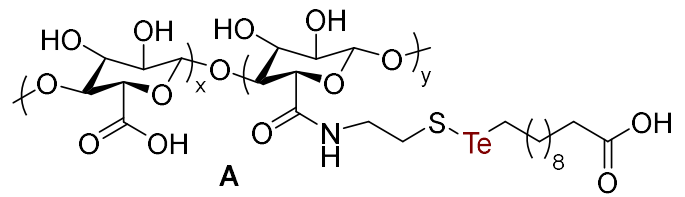

Biopolimeric nanogel for anticancer therapy<smiles>[R]CC(O)Cc1ccc(S(N)(=O)=O)cc1</smiles>

CAs inhibitors with anticancer activity<smiles></smiles><smiles>C=C[C@](C)(O)CCC[C@H]1C(=C)CC[C@]2(C)CCC[C@H](C)[C@@]12C</smiles>

ent-nakamurol A

b. Functionalisation of organotellurium compounds

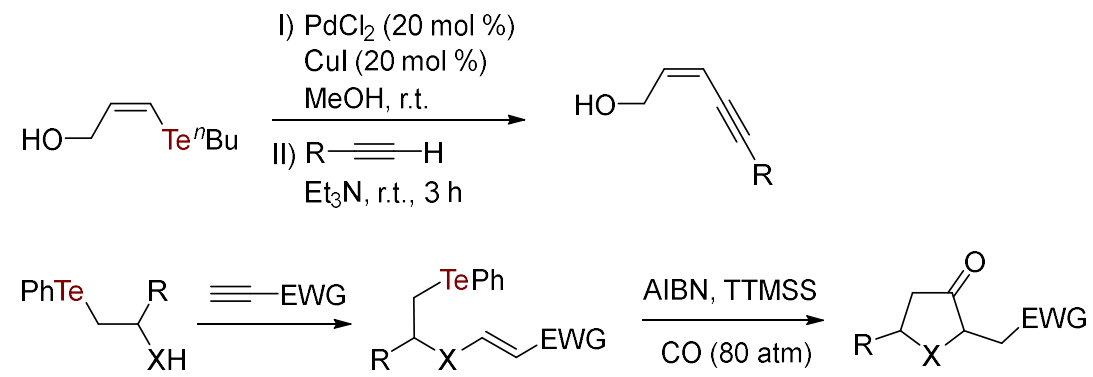

Figure 1. Biological and synthetic applications of organotellurium compounds (selected examples). Part a. A: a tellurium-containing biopolimeric nanogel for anticancer therapy [11]; B: tellurium-containing carbonic anhydrases inhibitors with anticancer activity [15]; LQ7: a ditelluride active as antiparasitic agent [29]; ent-nakamurol A: an organotelluride is involved in the key step of its total synthesis [35]. Part $\boldsymbol{b}$. Functionalization of organotellurium compounds [29,31].

Three-membered heterocycles such as epoxides and aziridines, often undergoing regioselective nucleophilic ring-opening reactions (NRORs), represent convenient starting materials for the synthesis of functionalised chalcogen-containing systems [36]. A number of ring-opening-based procedures for the synthesis of hydroxy- and amino-substituted selenides and tellurides have been developed over the last decade [37-42]. Such functionalised chalcogenides have also been employed as intermediates for the synthesis of valuable compounds $[35,43,44]$ and as organocatalysts for the asymmetric addition of diethylzinc to aldehydes [45].

In this communication, as a part of our growing interest in the study of the chemistry of organotellurium compounds, we report a study on the mechanism of an unexpected reaction of epoxides with elemental tellurium and lithium triethylborohydride, leading to the formation of $\beta$-hydroxy-alkyl ethyl tellurides.

\section{Materials and Methods}

\subsection{Experimental Section}

All reactions were carried out in an oven-dried glassware. Solvents were dried using a solvent purification system (Pure-Solv ${ }^{\mathrm{TM}}$, Darmstadt, Germany). All commercial materials were purchased from various commercial sources and used as received, without further purification. Flash column chromatography purifications were performed with Silica gel 60 (230-400 mesh). Thin layer chromatography was performed with TLC plates Silica gel $60 \mathrm{~F}_{254}$, which was visualised under UV light, or by staining with an ethanolic acid solution of $p$-anisaldehyde followed by heating. High resolution 
mass spectra (HRMS) were recorded by electrospray ionization (ESI). In the control experiment with degassed solvent, tetrahydrofuran (THF) was degassed by freeze-pump-thaw cycles $(\times 3)$ on the high vacuum line.

The ${ }^{1} \mathrm{H}$ and ${ }^{13} \mathrm{C}$-NMR spectra were recorded in $\mathrm{CDCl}_{3}$ with Mercury 400, Bruker 400 Ultrashield (Bruker, Milan, Italy), and Varian Gemini 200 spectrometers operating at $400 \mathrm{MHz}$ for ${ }^{1} \mathrm{H}$ and $100 \mathrm{MHz}$ for ${ }^{13} \mathrm{C}$. NMR signals were referenced to nondeuterated residual solvent signals: $7.26 \mathrm{ppm}$ for ${ }^{1} \mathrm{H}$ and $77.0 \mathrm{ppm}$ for ${ }^{13} \mathrm{C}$. The ${ }^{125} \mathrm{Te}-\mathrm{NMR}$ spectra were recorded in $\mathrm{CDCl}_{3}$ at $126 \mathrm{MHz}$ with a Bruker Ultrashield 400 Plus instrument (Bruker, Milan, Italy). (PhTe) $)_{2}$ was used as an external reference $(\delta=420 \mathrm{ppm})$. Chemical shifts $(\delta)$ are given in parts per million (ppm), and coupling constants $(J)$ are given in Hertz $(\mathrm{Hz})$, rounded to the nearest $0.1 \mathrm{~Hz}$. The ${ }^{1} \mathrm{H}-\mathrm{NMR}$ data are reported as follows: chemical shift, integration, multiplicity $(\mathrm{s}=$ singlet, $\mathrm{d}=$ doublet, $\mathrm{t}=$ triplet, $\mathrm{q}=$ quartet, $\mathrm{m}=$ multiplet, $\mathrm{dd}=$ doublet of doublet, $\mathrm{bs}=$ broad singlet, ap = apparent), coupling constant $(J)$, and assignment. Mass spectra (MS) were determined by ESI (Thermo Fisher Scientific, Milan, Italy).

Ditelluride 3a [46] and diselenide 6a [47] were prepared from 2-((benzyloxy)methyl)oxirane according to procedures reported in the literature.

\subsection{General Procedure for the Synthesis of $\beta$-Hydroxy-alkyl Ethyl Tellurides 2}

$\mathrm{Li}_{2} \mathrm{Te}_{2}$ was generated according to the literature $[48,49]$ from $1.0 \mathrm{~mL}$ of a $1 \mathrm{M}$ THF solution of $\mathrm{LiEt}_{3} \mathrm{BH}$ (1.0 mmol, 1.0 eq.) and elemental tellurium powder (128 mg, $1.0 \mathrm{mmol}, 1.0$ eq.), stirred at ambient temperature under inert atmosphere $\left(\mathrm{N}_{2}\right)$ for $6 \mathrm{~h}$. The dark red suspension of $\mathrm{Li}_{2} \mathrm{Te}_{2}$ in THF was treated with the epoxide (1.0 mmol, $1.0 \mathrm{eq}$.) and the reaction was stirred for $6 \mathrm{~h}$ at ambient temperature. Afterwards, the mixture was diluted with $\mathrm{Et}_{2} \mathrm{O}(10 \mathrm{~mL})$, filtered through a short pad of celite, and washed with saturated aq. $\mathrm{NH}_{4} \mathrm{Cl}$ and then with $\mathrm{H}_{2} \mathrm{O}(2 \times 5 \mathrm{~mL})$. The organic phase was dried over $\mathrm{Na}_{2} \mathrm{SO}_{4}$, filtered and evaporated under reduced pressure. The crude residue was then purified by flash chromatography $\left(\mathrm{Et}_{2} \mathrm{O} /\right.$ petroleum ether) to yield $\beta$-hydroxy-alkyl ethyl tellurides 2 .

\subsubsection{Synthesis of 1-(Benzyloxy)-3-(ethyltellanyl)propan-2-ol 2a}

Following the general procedure, 2-((benzyloxy)methyl)oxirane $(152 \mu \mathrm{L}, 1.0 \mathrm{mmol})$ and elemental tellurium $(128 \mathrm{mg}, 1.0 \mathrm{mmol})$ gave, after purification by flash chromatography $\left(\mathrm{Et}_{2} \mathrm{O} /\right.$ petroleum ether 1:1), 2a as a colourless oil $(61 \mathrm{mg}, 38 \%)[49] .{ }^{1} \mathrm{H}-\mathrm{NMR}\left(200 \mathrm{MHz}, \mathrm{CDCl}_{3}\right): \delta(\mathrm{ppm}) 1.60(3 \mathrm{H}, \mathrm{t}, J=7.6 \mathrm{~Hz}$, $\left.\mathrm{CH}_{3}\right), 2.63\left(2 \mathrm{H}\right.$, ap q, $\left.J=7.6 \mathrm{~Hz}, \mathrm{CH}_{3} \mathrm{CH}_{2} \mathrm{Te}\right), 2.63(1 \mathrm{H}, \mathrm{bs}, \mathrm{OH}), 2.76-2.89\left(2 \mathrm{H}, \mathrm{m}, \mathrm{CH}_{2} \mathrm{Te}\right), 3.41-3.48$ $\left(1 \mathrm{H}, \mathrm{m}, \mathrm{CH}_{\mathrm{a}} \mathrm{H}_{\mathrm{b}} \mathrm{O}\right), 3.59\left(1 \mathrm{H}, \mathrm{dd}, J=4.2,9.6 \mathrm{~Hz}, \mathrm{CH}_{\mathrm{a}} \mathrm{H}_{\mathrm{b}} \mathrm{O}\right), 3.45-3.97(1 \mathrm{H}, \mathrm{m}, \mathrm{CHOH}), 4.55(2 \mathrm{H}$, ap s, $\left.\mathrm{CH}_{2} \mathrm{Ph}\right), 7.26-7.40(5 \mathrm{H}, \mathrm{m}) .{ }^{13} \mathrm{C}-\mathrm{NMR}(100 \mathrm{MHz}, \mathrm{CDCl} 3): \delta(\mathrm{ppm})-4.5\left(\mathrm{CH}_{3} \mathrm{CH}_{2} \mathrm{Te}\right), 7.7\left(\mathrm{CH}_{2} \mathrm{Te}\right), 17.8$, 70.6, 73.4, 74.3, 127.8, 127.8, 128.4, 137.9. ${ }^{125} \mathrm{Te}-\mathrm{NMR}(126 \mathrm{MHz}, \mathrm{CDCl} 3): \delta$ (ppm) 213.6.

\subsubsection{Synthesis of 1-(Ethyltellanyl)-3-isopropoxypropan-2-olol $\mathbf{2 b}$}

Following the general procedure, 2-(isopropoxymethyl)oxirane ( $32 \mu \mathrm{L}, 0.25 \mathrm{mmol}), \mathrm{LiEt}_{3} \mathrm{BH}$ $(0.25 \mathrm{~mL}, 0.25 \mathrm{mmol})$ and elemental tellurium $(32 \mathrm{mg}, 0.25 \mathrm{mmol})$ gave, after purification by flash chromatography $\left(\mathrm{Et}_{2} \mathrm{O} /\right.$ petroleum ether $\left.1: 1\right), \mathbf{2 b}$ as a colourless oil $(30 \mathrm{mg}, 44 \%) .{ }^{1} \mathrm{H}-\mathrm{NMR}(200 \mathrm{MHz}$, $\left.\mathrm{CDCl}_{3}\right): \delta(\mathrm{ppm}) 1.18(6 \mathrm{H}$, ap d,$J=6.5 \mathrm{~Hz}), 1.62(3 \mathrm{H}, \mathrm{t}, J=7.6 \mathrm{~Hz}), 2.64(2 \mathrm{H}$, ap q, $J=7.6 \mathrm{~Hz}), 2.75(1 \mathrm{H}$, ap $\mathrm{s}, \mathrm{OH}), 2.74-2.92\left(\mathrm{CH}_{2} \mathrm{Te}\right), 3.38\left(1 \mathrm{H}, \mathrm{dd}, J=6.7,9.3 \mathrm{~Hz}, \mathrm{CH}_{\mathrm{a}} \mathrm{H}_{\mathrm{b}} \mathrm{O}\right), 3.54\left(1 \mathrm{H}, \mathrm{dd}, J=3.6,9.3 \mathrm{~Hz}, \mathrm{CH}_{\mathrm{a}} \mathrm{H}_{\mathrm{b}} \mathrm{O}\right)$, 3.59-3.67 (1H, m, CH $\left.\left(\mathrm{CH}_{3}\right)_{2}\right), 3.83-3.92(1 \mathrm{H}, \mathrm{m}, \mathrm{CHOH}) .{ }^{13} \mathrm{C}-\mathrm{NMR}\left(50 \mathrm{MHz}, \mathrm{CDCl}_{3}\right): \delta(\mathrm{ppm})-4.6$ $\left(\mathrm{CH}_{3} \mathrm{CH}_{2} \mathrm{Te}\right), 7.6\left(\mathrm{CH}_{2} \mathrm{Te}\right), 17.5\left(\mathrm{CH}_{3}\right), 21.8,71.3,71.6,72.2$. MS (ESI, positive) $[\mathrm{M}+\mathrm{H}]^{+} 276.8$.

\subsubsection{Synthesis of 1-(Ethyltellanyl)hexan-2-ol 2c}

Following the general procedure, 2-butyloxirane ( $25 \mathrm{mg}, 0.25 \mathrm{mmol}), \operatorname{LiEt}_{3} \mathrm{BH}(0.25 \mathrm{~mL}, 0.25 \mathrm{mmol})$ and elemental tellurium $(32 \mathrm{mg}, 0.25 \mathrm{mmol})$ gave, after flash chromatography $\left(\mathrm{Et}_{2} \mathrm{O} /\right.$ petroleum ether 2:1), $2 \mathrm{~d}$ as a colourless oil (31 mg, 48\%) [49]. ${ }^{1} \mathrm{H}-\mathrm{NMR}\left(200 \mathrm{MHz}, \mathrm{CDCl}_{3}\right): \delta(\mathrm{ppm}): 0.86-0.97(3 \mathrm{H}, \mathrm{m}$, $\left.\mathrm{CH}_{3}\right), 1.24-1.62\left(6 \mathrm{H}, \mathrm{m}, \mathrm{CH}_{2}\right), 1.61(3 \mathrm{H}, \mathrm{t}, J=7.6 \mathrm{~Hz}), 2.16(1 \mathrm{H}, \mathrm{ap} \mathrm{s}, \mathrm{OH}), 2.64(2 \mathrm{H}, \mathrm{ap} \mathrm{q}, J=7.6 \mathrm{~Hz})$, 
2.71-2.94 (2H, m, $\left.\mathrm{CH}_{2} \mathrm{Te}\right), 3.73-3.78(1 \mathrm{H}, \mathrm{m}, \mathrm{CHOH}) .{ }^{13} \mathrm{C}-\mathrm{NMR}\left(100 \mathrm{MHz}, \mathrm{CDCl}_{3}\right) ; \delta(\mathrm{ppm}):-4.7,17.6$, 14.6, 15.3, 23.3, 28.6, 38.0, 73.3. HRMS (ESI) calculated for $\mathrm{C}_{8} \mathrm{H}_{18} \mathrm{NaOTe:} 283.0318$; found: 283.0331.

\subsubsection{Synthesis of 1-(Ethyltellanyl)propan-2-ol 2d}

Following the general procedure, 2-methyloxirane (70 $\mu \mathrm{L}, 1.0 \mathrm{mmol}), \mathrm{LiEt}_{3} \mathrm{BH}(1.0 \mathrm{~mL}, 1.0 \mathrm{mmol})$ and elemental tellurium (126 mg, $1.0 \mathrm{mmol})$ gave, after flash chromatography $\left(\mathrm{Et}_{2} \mathrm{O} /\right.$ petroleum ether 1:1), $2 \mathrm{~d}$ as a colourless oil (45 mg, 41\%) [49]. ${ }^{1} \mathrm{H}-\mathrm{NMR}\left(200 \mathrm{MHz}, \mathrm{CDCl}_{3}\right): \delta(\mathrm{ppm}) 1.30(3 \mathrm{H}, \mathrm{d}$, $\left.J=6.1 \mathrm{~Hz}, \mathrm{CH}_{3}\right), 1.61\left(3 \mathrm{H}, \mathrm{t}, J=7.6 \mathrm{~Hz}, \mathrm{CH}_{3} \mathrm{CH}_{2}\right), 2.24(1 \mathrm{H}, \mathrm{bs}, \mathrm{OH}), 2.63-2.72\left(2 \mathrm{H}, \mathrm{m}, \mathrm{CH}_{3} \mathrm{CH}_{2}\right), 2.73$ $\left(1 \mathrm{H}, \mathrm{dd}, J=12.2,7.4 \mathrm{~Hz}, \mathrm{CH}_{\mathrm{a}} \mathrm{H}_{\mathrm{b}} \mathrm{Te}\right), 2.87\left(1 \mathrm{H}, \mathrm{dd}, J=4.6,12.2 \mathrm{~Hz}, \mathrm{CH}_{\mathrm{a}} \mathrm{H}_{\mathrm{b}} \mathrm{Te}\right), 3.78-4.02(1 \mathrm{H}, \mathrm{m}, \mathrm{CHOH})$. ${ }^{13} \mathrm{C}-\mathrm{NMR}\left(100 \mathrm{MHz}, \mathrm{CDCl}_{3}\right): \delta(\mathrm{ppm})-4.7\left(\mathrm{CH}_{3} \mathrm{CH}_{2} \mathrm{Te}\right), 16.0,17.7,23.7,67.3$.

Copy of ${ }^{1} \mathrm{H}-\mathrm{NMR},{ }^{13} \mathrm{C}-\mathrm{NMR}$, and ${ }^{125} \mathrm{Te}-\mathrm{NMR}$ spectra can be found in Supplementary Materials.

\subsubsection{Control Experiment with the Radical Inhibitor}

A solution of 3,3'-ditellanediylbis(1-(benzyloxy)propan-2-ol) 3a (29 mg, $0.05 \mathrm{mmol}$ ) and BHT (3,5-di-tert-butyl-4-hydroxytoluene, $22 \mathrm{mg}, 0.1 \mathrm{mmol}$ ) in dry THF $(2 \mathrm{~mL})$ was treated with triethylborane $(0.1 \mathrm{mmol}, 100 \mu \mathrm{L}$ of a $1 \mathrm{M}$ solution in THF). The reaction mixture was stirred at ambient temperature for $6 \mathrm{~h}$, and afterwards, the solvent was removed under vacuum.

\section{Results}

During the course of our studies on the reactivity of strained heterocycles with selenium-centered nucleophiles we developed convenient routes towards generating a variety of hydroxy-, amino-, and mercapto-substituted Se-containing systems [50-53]. For example, through the tuning of the stoichiometry and the conditions of the reaction of $\left(\mathrm{Me}_{3} \mathrm{Si}\right)_{2} \mathrm{Se}[($ bis(trimethylsilyl)selenide, a synthetic equivalent of hydrogen selenide] with epoxides, thiiranes, and aziridines, we were able to successfully achieve a range of functionalised selenols [50], selenides, and diselenides [47].

Attracted by the synthetic utility and versatility of organotellurium compounds, we recently moved to evaluate the chemistry of tellurium-centered nucleophiles with strained heterocycles [46,49]. The poor stability of $\left(\mathrm{Me}_{3} \mathrm{Si}\right)_{2} \mathrm{Te}[48,49]$ prompted us to employ dilithium telluride and dilithium ditelluride, generated from elemental tellurium and lithium triethylborohydride (superhydride), as tellurenylation reagents for the NRORs of epoxides and aziridines [49]. However, while the ring-opening of epoxides with $\mathrm{Li}_{2} \mathrm{Te}$ provided access to symmetrical $\beta$-hydroxy-tellurides $\mathbf{1}$ (Scheme 1 , part a), the reaction with $\mathrm{Li}_{2} \mathrm{Te}_{2}$ gave almost exclusively $\beta$-hydroxy-alkyl ethyl tellurides 2 instead of the expected $\beta$-hydroxy-ditellurides 3 , which were isolated only in trace amounts (Scheme 1 , part b). Intrigued by this result, we wished to deeper investigate such a transformation in order to establish the mechanism involved in the formation of asymmetrical $\beta$-hydroxy-alkyl ethyl tellurides 2.

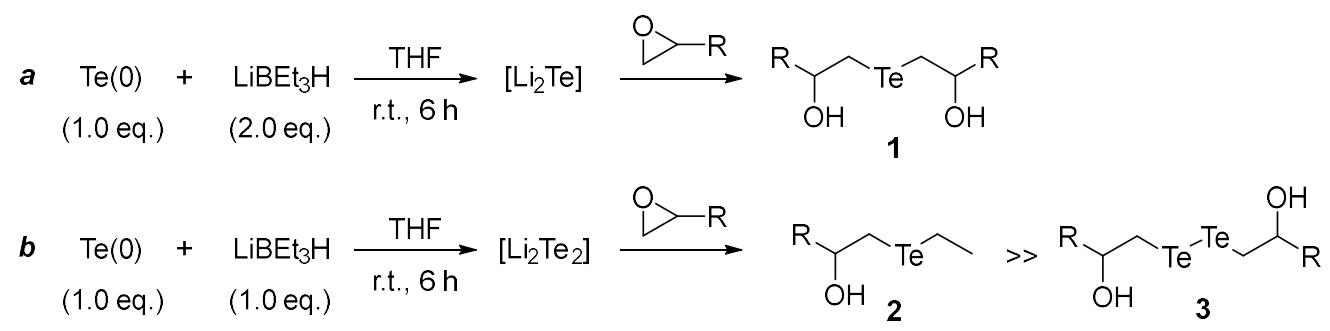

Scheme 1. Reactivity of epoxides with $\mathrm{Li}_{2} \mathrm{Te}_{\mathrm{e}}$ and $\mathrm{Li}_{2} \mathrm{Te}_{2}$, generated from elemental tellurium under lithium triethylborohydride conditions. (a) Synthesis of tellurides 1. (b) Formation of $\beta$-hydroxy-alkyl ethyl tellurides 2 .

Notably, this ethyltellurenylation reaction proved to be general and differently substituted epoxides could be smoothly converted into the corresponding $\beta$-hydroxy-alkyl ethyl tellurides through this one-pot multistep procedure (Scheme 2). 


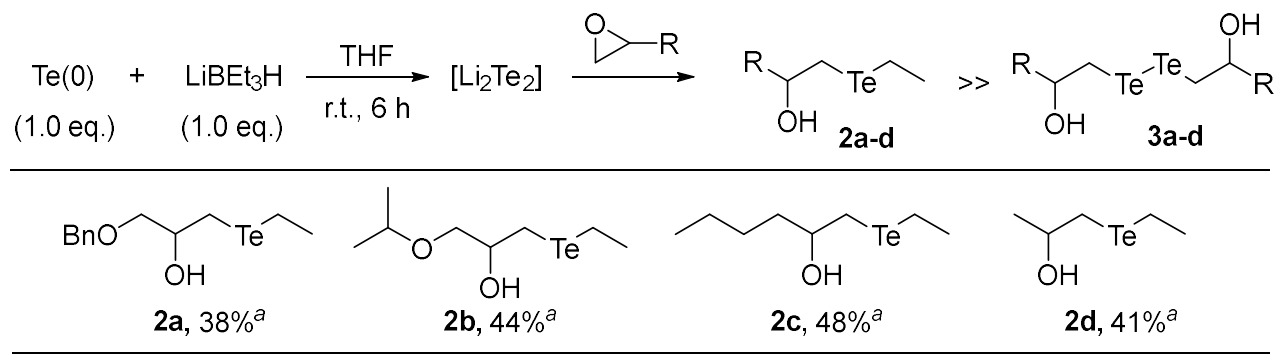

Scheme 2. One-pot ethyltellurenylation of epoxides. Traces of ditellurides $3 a-d ~(3 \%-7 \%)$ were detected in the crude material. Isolated yields are reported.

A plausible explanation for the formation of unsymmetrical tellurides 2 involves the transmetalation of triethylborane with $\beta$-hydroxy-ditellurides 3. However, an alternative path could proceed through the ring-opening of epoxides with tris(ethyltelluro)borane 4 (Scheme 3) which, in principle, could be generated from dilithium ditelluride and triethyl borane. A series of control experiments were therefore undertaken in order to test these hypotheses.

We initially evaluated whether tris(ethyltelluro)borane 4 could be generated upon the treatment of elemental tellurium with lithium triethylborohydride. However, the formation of $\mathbf{4}$ was not observed under the standard reaction conditions (Scheme 3, reaction $a$ ). Traces of 4 were not detected performing the reaction in a coaxial NMR tube and monitoring its progress over the time.

On the basis of these results, we next turned our attention to evaluating whether under the studied conditions ditellurides 3 could behave as precursors of $\beta$-hydroxy-alkyl ethyl tellurides 2 . We recently developed an on-water methodology to access functionalised dialkyl ditellurides from elemental tellurium, sodium hydroxymethanesulfinate, and strained heterocycles [46]. Therefore, we employed this route to prepare $\beta$-hydroxy-ditelluride $3 \mathbf{a}$ and then we studied its reactivity with organoboranes. As a result, $3 \mathbf{a}$ was thus treated with lithium triethylborohydride and, pleasingly, $\beta$-hydroxy-alkyl ethyl telluride $2 \mathbf{a}$ was formed in $42 \%$ yield (Scheme 3, reaction $b$ ). However, under these conditions the alkyltellurolate $\mathbf{5 a}$, arising from the $\mathrm{LiBEt}_{3} \mathrm{H}$-induced reduction of the ditelluride $\mathbf{3 a}$, could be the species actually involved in the formation of 2a. Unequivocal proof for the direct involvement of ditelluride $3 a$ and triethylborane was obtained by the reaction of these two compounds which, in the absence of hydrides, afforded 2a in 48\% yield (Scheme 3, reaction c). Notably, related diselenide 6a reacted slowly with triethylborane under the same conditions and only traces $(<5 \%)$ of unsymmetrical ethyl-selenide $7 \mathbf{a}$ were detected after $6 \mathrm{~h}$ (Scheme 3, reaction $d$ ).

Trialkyl boranes readily undergo radical reactions generating alkyl radicals. Such processes can be initiated by oxygen, light or radical initiators, such as AIBN (Azobisisobutyronitrile) [54,55]. Additionally, ditellurides have been demonstrated to easily react with alkyl radicals, exhibiting remarkable radical-trapping activity [56]. On the basis of these considerations and supported by a literature precedent describing the reactivity of diphenyl ditelluride with organoboranes [57], we hypothesised a radical process involving ditellurides 3 and ethyl radicals. Control experiments performed using 3,5-di-tert-butyl-4-hydroxytoluene (BHT) as a radical inhibitor further demonstrated a radical pathway. Additionally, performing reactions b and c (Scheme 3) in the dark had no significant effect on the reaction outcome, showing that light was not required for the process leading to $2 a$. On the other hand, when degassed tetrahydrofuran (THF) was used as the solvent, the ethyltellurenylation reaction was strongly inhibited and only traces of $\mathbf{2 a}(<10 \%)$ were isolated. 

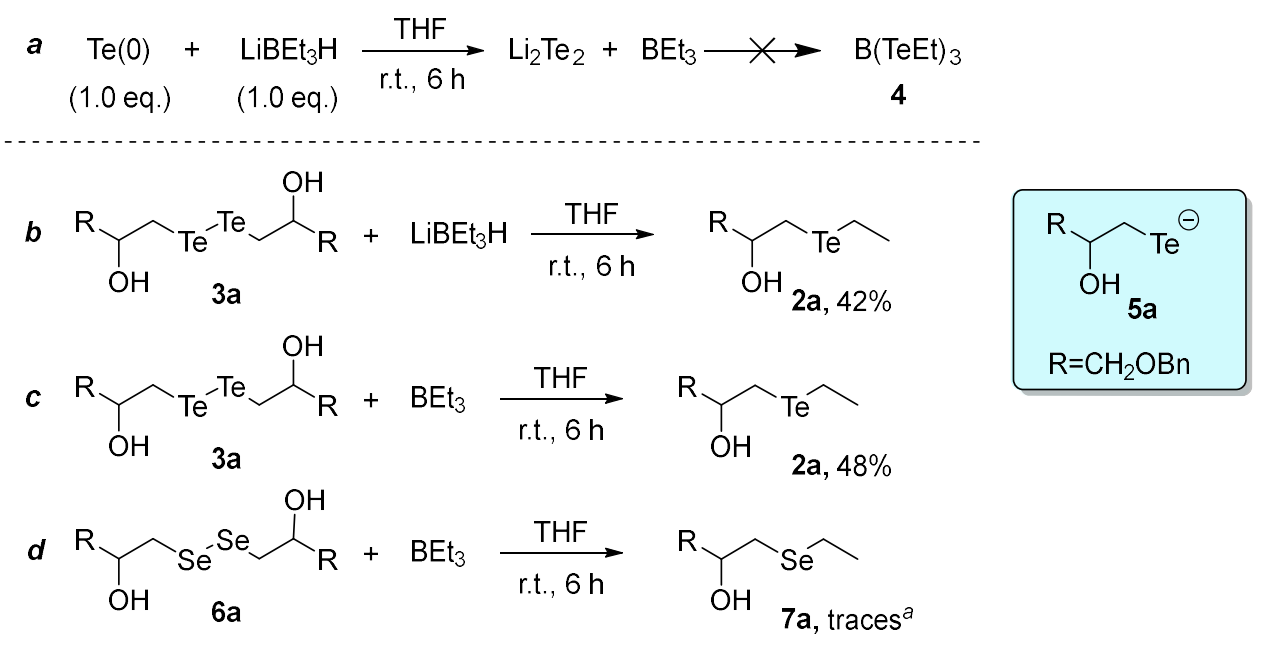

$\mathrm{R}=\mathrm{CH}_{2} \mathrm{OBn}$

Scheme 3. Control experiments. ${ }^{a}$ Only traces $(<5 \%)$ of $7 \mathbf{a}$ were detected by ${ }^{1} \mathrm{H}-\mathrm{NMR}$ of the crude material.

On the basis of the control experiments and previous reports, a proposed reaction mechanism is reported in Scheme 4. The first step (I) involves the reduction of elemental tellurium with lithium triethylborohydride, leading to the formation of dilithium ditelluride and triethylborane [58]. Subsequently (II), $\mathrm{Li}_{2} \mathrm{Te}_{2}$ reacts with two equivalents of epoxide to afford the corresponding ditelluride 3 through a regioselective nucleophilic ring-opening reaction. The following transmetalation of $\mathrm{Et}_{3} \mathrm{~B}$ with 3 reasonably proceeds through the oxygen-mediated formation of ethyl radicals (III) $[54,55]$ which, in turn, react with ditelluride 3 providing unsymmetrical $\beta$-hydroxy-alkyl ethyl telluride 2 through an $\mathrm{S}_{\mathrm{H}} 2$ process (IV) $[59,60]$. The tellurium-centered radical 8, formed in the $\mathrm{S}_{\mathrm{H}} 2$ reaction, undergoes typical propagation and termination processes, including the recombination with a second equivalent of 8 providing ditelluride 3 [61]. Furthermore, the reaction of $\mathbf{8}$ with oxygen or borylperoxyl radicals (V) would afford reactive tellurenyl peroxides which plausibly decompose, thus explaining the rather low yield of the transmetalation reaction and the absence of ditelluride 3 , or unreacted epoxide in the crude mixture.

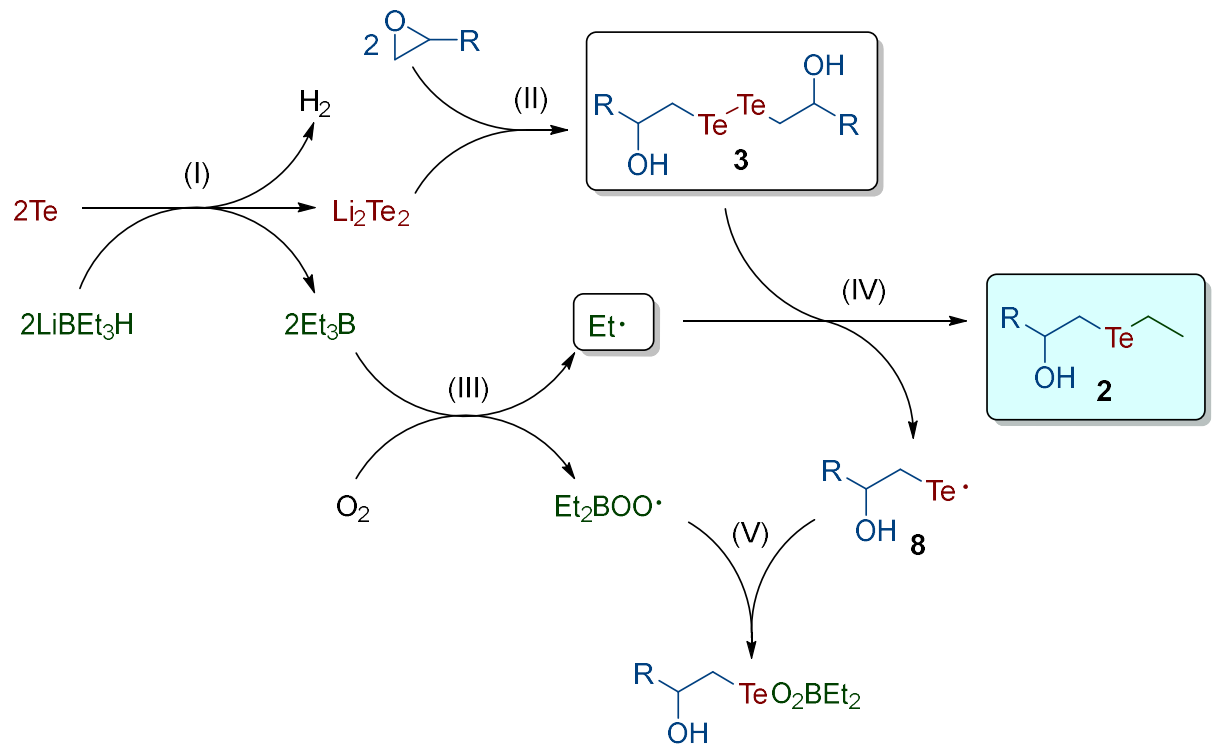

Scheme 4. Proposed mechanism for the formation of unsymmetrical $\beta$-hydroxy-alkyl ethyl tellurides 2. 


\section{Conclusions}

In conclusion, we have described a one-pot multistep reaction in which epoxides are converted into the corresponding unsymmetrical $\beta$-hydroxy-alkyl ethyl tellurides upon treatment with elemental tellurium under lithium triethylborohydride-reducing conditions. The reaction mechanism was experimentally investigated; $\beta$-hydroxy ditellurides and triethyl borane were demonstrated to be the key species involved in this one-pot ethyltellurenylation reaction. The transmetalation of triethyl borane with hydroxy-dialkyl ditellurides, reasonably occurring through an oxygen-induced $\mathrm{S}_{\mathrm{H}} 2$ mechanism, represents the key step of the process. The findings here described can be exploited for the development of novel general methodologies towards the synthesis of synthetically and biologically valuable complex $\mathrm{sp}^{3}$-rich unsymmetrical tellurides. Further studies on the application of this reaction to functionalised boranes (and boronic esters) for the preparation and the elaboration of poly-functionalised unsymmetrical tellurides are currently ongoing in our laboratories.

Supplementary Materials: The following are available online at http://www.mdpi.com/2624-8549/2/3/41/s1, Figure S1. ${ }^{1} \mathrm{H}$ NMR spectrum of compound $2 \mathbf{a}(\mathrm{CDCl} 3,400 \mathrm{MHz})$; Figure S2. ${ }^{13} \mathrm{C}$ NMR spectrum of compound 2a $(\mathrm{CDCl} 3,100 \mathrm{MHz})$; Figure S3. ${ }^{125} \mathrm{Te} \mathrm{NMR}$ spectrum of compound 2a $(\mathrm{CDCl} 3,126 \mathrm{MHz})$; Figure S4. ${ }^{1} \mathrm{H}$ NMR spectrum of compound $\mathbf{2 b}(\mathrm{CDCl} 3,400 \mathrm{MHz})$; Figure S5. ${ }^{13} \mathrm{C}$ NMR spectrum of compound $\mathbf{2 b}(\mathrm{CDCl} 3,100 \mathrm{MHz})$; Figure S6. ${ }^{1} \mathrm{H}$ NMR spectrum of compound $2 \mathrm{~d}(\mathrm{CDCl} 3,400 \mathrm{MHz})$; Figure S7. ${ }^{13} \mathrm{C}$ NMR spectrum of compound 2d (CDCl3, $100 \mathrm{MHz})$; Figure S8. ${ }^{125} \mathrm{Te}$ NMR spectrum of compound 2d (CDCl3, $\left.126 \mathrm{MHz}\right)$; Figure S9. ${ }^{1} \mathrm{H}$ NMR spectrum of compound 3a (CDCl3, $400 \mathrm{MHz})$; Figure S10. ${ }^{13} \mathrm{C}$ NMR spectrum of compound 3a $(\mathrm{CDCl} 3,100 \mathrm{MHz})$; Figure S11. ${ }^{125} \mathrm{Te}$ NMR spectrum of compound 3a $(\mathrm{CDCl} 3,126 \mathrm{MHz})$.

Author Contributions: Conceptualization, methodology, investigation, data curation, writing-original draft preparation, writing-review and editing, D.T. and A.C.; All authors have read and agreed to the published version of the manuscript.

Funding: This research received no external funding.

Acknowledgments: We thank MIUR-Italy ("Progetto Dipartimenti di Eccellenza 2018-2022" allocated to the Department of Chemistry "Ugo Schiff”).

Conflicts of Interest: The authors declare no conflict of interest.

\section{References and Notes}

1. Lenardão, E.J.; Santi, C.; Sancineto, L. New Frontiers in Organoselenium Compounds; Springer: New York, NY, USA, 2018.

2. Wirth, T. Organoselenium Chemistry: Synthesis and Reactions; Wiley-VCH Verlag GmbH \& Co: Weinheim, Germany, 2012.

3. Petragnani, N.; Stefani, H.A. Tellurium in Organic Synthesis, 2nd ed.; Elsevier: Amsterdam, The Netherlands, 2007.

4. Angeli, A.; Carta, F.; Donnini, S.; Capperucci, A.; Ferraroni, M.; Tanini, D.; Supuran, C.T. Selenolesterase enzyme activity of carbonic anhydrases. Chem. Commun. 2020, 56, 4444-4447. [CrossRef] [PubMed]

5. Gandin, V.; Khalkar, P.; Braude, J.; Fernandes, A.P. Organic selenium compounds as potential chemotherapeutic agents for improved cancer treatment. Free Radic. Biol. Med. 2018, 127, 80-97. [CrossRef]

6. Kumar, S.; Yan, J.; Poon, J.; Singh, V.P.; Lu, X.; Karlsson Ott, M.; Engman, L.; Kumar, S. Multifunctional Antioxidants: Regenerable Radical-Trapping and Hydroperoxide-Decomposing Ebselenols. Angew. Chem. Int. Ed. 2016, 55, 3729-3733. [CrossRef]

7. Ba, L.A.; Doring, M.; Jamier, V.; Jacob, C. Tellurium: An element with great biological potency and potential. Org. Biomol. Chem. 2010, 8, 4203-4216. [CrossRef]

8. For a review see: Nogueira, C.W.; Zeni, G.; Rocha, J.B.T. Organoselenium and organotellurium compounds: Toxicology and pharmacology. Chem. Rev. 2004, 104, 6255-6286. [CrossRef] [PubMed]

9. Comasseto, J.V.; Gariani, R.A. Biotransformations on Organic Selenides and Tellurides: Synthetic Applications. Tetrahedron 2009, 65, 8447-8459. [CrossRef]

10. Liu, J.; Ma, X.; Tong, Y.; Lang, M. Self-healing polyurethane based on ditelluride bonds. Appl. Surf. Sci. 2018, 455, 318-325. [CrossRef] 
11. Xia, X.; Xiang, X.; Huang, F.; Zhang, Z.; Han, L. A tellurylsulfide bond-containing redox-responsive superparamagnetic nanogel with acid-responsiveness for efficient anticancer therapy. Chem. Commun. 2017, 53, 13141-13144. [CrossRef]

12. Engman, L.; Al-Maharik, N.; McNaughton, M.; Birmingham, A.; Powis, G. Thioredoxin reductase and cancer cell growth inhibition by organotellurium antioxidants. Anti-Cancer Drugs 2003, 14, 153-161. [CrossRef]

13. Rooseboom, M.; Vermeulen, N.P.E.; Durgut, F.; Commandeur, J.N.M. Comparative study on the bioactivation mechanisms and cytotoxicity of Te-phenyl-L-tellurocysteine, Se-Phenyl-L-selenocysteine, and S-Phenyl-L-cysteine. Chem. Res. Toxicol. 2002, 15, 1610-1618. [CrossRef]

14. Lin, T.; Ding, Z.; Li, N.; Xu, J.; Luo, G.; Liu, J.; Shen, J. 2-Tellurium-bridged $\beta$-cyclodextrin, a thioredoxin reductase inhibitor, sensitizes human breast cancer cells to TRAIL-induced apoptosis through DR5 induction and NF-kB suppression. Carcinogenesis 2010, 32, 154-167. [CrossRef] [PubMed]

15. Tanini, D.; Ricci, L.; Capperucci, A.; Di Cesare Mannelli, L.; Ghelardini, C.; Peat, T.S.; Carta, F.; Angeli, A.; Supuran, C.T. Synthesis of novel tellurides bearing benzensulfonamide moiety as carbonic anhydrase inhibitors with antitumor activity. Eur. J. Med. Chem. 2019, 181, 111586. [CrossRef] [PubMed]

16. Tanini, D.; Capperucci, A.; Supuran, C.T.; Angeli, A. Sulfur, selenium and tellurium containing amines act as effective carbonic anhydrase activators. Bioorg. Chem. 2019, 87, 516-522. [CrossRef]

17. Angeli, A.; Tanini, D.; Capperucci, A.; Supuran, C.T. First evaluation of organotellurium derivatives as carbonic anhydrase I, II, IV, VII and IX inhibitors. Bioorg. Chem. 2018, 76, 268-272. [CrossRef]

18. Rettig, I.D.; Van, J.; Brauer, J.B.; Luo, W.; McCormick, T.M. Tellurorhodamine photocatalyzed aerobic oxidation of organo-silanes and phosphines by visible-light. Dalton Trans. 2019, 48, 5665-5673. [CrossRef] [PubMed]

19. Tanini, D.; Lupori, B.; Malevolti, G.; Ambrosi, M.; Lo Nostro, P.; Capperucci, A. Direct biocatalysed synthesis of first sulfur-, selenium- and tellurium- containing L-ascorbyl hybrid derivatives with radical trapping and GPx-like properties. Chem. Commun. 2019, 55, 5705-5708. [CrossRef]

20. Tanini, D.; Grechi, A.; Ricci, L.; Dei, S.; Teodori, E.; Capperucci, A. Novel functionalized organotellurides with enhanced thiol peroxidase catalytic activity. New J. Chem. 2018, 42, 6077-6083. [CrossRef]

21. Bortoli, M.; Torsello, M.; Bickelhaupt, F.M.; Orian, L. Role of the Chalcogen (S, Se, Te) in the Oxidation Mechanism of the Glutathione Peroxidase Active Site. ChemPhysChem 2017, 18, 2990-2998. [CrossRef]

22. Singh, V.P.; Poon, J.F.; Engman, L. Catalytic Antioxidants: Regenerable Tellurium Analogues of Vitamin E. Org. Lett. 2013, 15, 6274-6277. [CrossRef]

23. Braga, A.L.; Alberto, E.E.; Soares, L.C.; Rocha, J.B.T.; Sudati, J.H.; Roos, D.H. Synthesis of telluroamino acid derivatives with remarkable GPx like activity. Org. Biol. Chem. 2009, 7, 43-45. [CrossRef]

24. Giles, G.I.; Fry, F.H.; Tasker, K.M.; Holme, A.L.; Peers, C.; Green, K.N.; Klotz, L.O.; Sies, H.; Jacob, C. Evaluation of sulfur, selenium and tellurium catalysts with antioxidant potential. Org. Biomol. Chem. 2003, 1, 4317-4322. [CrossRef] [PubMed]

25. Tiano, L.; Fedeli, D.; Santroni, A.M.; Villarini, M.; Engman, L.; Falcioni, G. Effect of three diaryl tellurides, and an organoselenium compound in trout erythrocytes exposed to oxidative stress in vitro. Mutat. Res. 2000, 464, 269-277. [CrossRef]

26. Petragnani, N.; Stefani, H.A. Advances in organic tellurium chemistry. Tetrahedron 2005, 61, $1613-1679$. [CrossRef]

27. Comasseto, J.V.; Barrientos-Astigarraga, R.E. Add a Little Tellurium to Your Synthetic Plans! Aldrichim. Acta 2000, 33, 66-78.

28. Stefani, H.A.; Pena, J.M.; Manarin, F.; Ando, R.A.; Leal, M.; Petragnani, N. Negishi cross-coupling of organotellurium compounds: Synthesis of biaryls, aryl-, and diaryl acetylenes. Tetrahedron Lett. 2011, 52, 4398-4401. [CrossRef]

29. Berlin, S.; Ericsson, C.; Engman, L. Radical Carbonylation/Reductive Cyclization for the Construction of Tetrahydrofuran-3-ones and Pyrrolidin-3-ones. J. Org. Chem. 2003, 68, 8386-8396. [CrossRef] [PubMed]

30. Tucci, F.C.; Chieffi, A.; Comasseto, J.V.; Marino, J.P. Tellurium in Organic Synthesis. Preparation of Z-Vinylic Cuprates from Z-Vinylic Tellurides and Their Reaction with Enones and Epoxides. J. Org. Chem. 1996, 61, 4975-4989. [CrossRef]

31. Zeni, G.; Comasseto, J.V. Coupling of Z-vinylic tellurides with alkynes catalysed by $\mathrm{PdCl}_{2} \mathrm{CuI}$ : Synthesis of Z-enynes and Z-enediynes. Tetrahedron Lett. 1999, 40, 4619-4622. [CrossRef] 
32. Hirata, K.; Kotoku, M.; Seki, N.; Maeba, T.; Maeda, K.; Hirashima, S.; Sakai, T.; Obika, S.; Hori, A.; Hase, Y.; et al. SAR Exploration Guided by LE and Fsp ${ }^{3}$ : Discovery of a Selective and Orally Efficacious ROR $\gamma$ Inhibitor. ACS Med. Chem. Lett. 2016, 7, 23-27. [CrossRef]

33. Lovering, F.; Bikker, J.; Humblet, C. Escape from Flatland: Increasing Saturation as an Approach to Improving Clinical Success. J. Med. Chem. 2009, 52, 6752-6756. [CrossRef]

34. Bandeira, P.T.; Souza, J.P.A.; Scariot, D.B.; Garcia, F.P.; Nakamura, C.V.; de Oliveira, A.R.M.; Piovan, L. Diacetal Ditellurides as Highly Active and Selective Antiparasitic Agents toward Leishmania amazonensis. ACS Med. Chem. Lett. 2019, 10, 806-810. [CrossRef] [PubMed]

35. Díaz, S.; Cuesta, J.; Gonzàlez, A.; Bonjoch, J. Synthesis of (-)-Nakamurol A and Assignment of Absolute Configuration of Diterpenoid (+)-Nakamurol A. J. Org. Chem. 2003, 68, 7400-7406. [CrossRef]

36. Tanini, D.; Capperucci, A. Ring opening reactions of heterocycles with selenium and tellurium nucleophiles. New J. Chem. 2019, 43, 11451-11468. [CrossRef]

37. Silva, P.C.; Borges, E.L.; Lima, D.B.; Jacob, R.G.; Lenardão, E.J.; Perin, G.; Silva, M.S. A simple and non-conventional method for the synthesis of selected $\beta$-arylalkylchalcogeno substituted alcohols, amines and carboxylic acids. Arkivoc 2016, 5, 376-389. [CrossRef]

38. Ganesh, V.; Chandrasekaran, S. One-Pot Synthesis of $\beta$-Amino/ $\beta$-Hydroxy Selenides and Sulfides from Aziridines and Epoxides. Synthesis 2009, 2009, 3267-3278. [CrossRef]

39. Braga, A.L.; Schwab, R.S.; Alberto, E.E.; Salman, S.M.; Vargas, J.; Azaredo, J.B. Ring opening of unprotected aziridines by zinc selenolates in a biphasic system. Tetrahedron Lett. 2009, 50, 2309-2311. [CrossRef]

40. Santi, C.; Santoro, S.; Battistelli, B.; Testaferri, L.; Tiecco, M. Preparation of the First Bench-Stable Phenyl Selenolate: An Interesting “On Water” Nucleophilic Reagent. Eur. J. Org. Chem. 2008, 5387-5390. [CrossRef]

41. Vargas, F.; Comasseto, J.V. Practical synthesis of chiral $\beta$-telluro amines by ring-opening reaction of aziridines. J. Organomet. Chem. 2009, 694, 122-126. [CrossRef]

42. Leng, T.; Wu, G.; Zhou, Y.-B.; Gao, W.; Ding, J.; Huang, X.; Liu, M.; Wu, H. Silver-Catalyzed One-Pot Three-Component Selective Synthesis of $\beta$-Hydroxy Selenides. Adv. Synth. Catal. 2018, 360, 4336-4340. [CrossRef]

43. Alvano Pérez-Bautista, J.; Sosa-Rivadeneyra, M.; Quintero, L.; Hüpfl, H.; Tejeda-Dominguez F., A.; Sartillo-Piscil, F. Highly stereoselective aziridine ring-opening with phenylselenide anion and selective intramolecular aldol closure for the enantiopure synthesis of $\gamma$-aminocyclopentene derivatives. Tetrahedron Lett. 2009, 50, 5572-5574. [CrossRef]

44. Liu, L.; Sun, Y.; Wang, J.; Ou, W.; Wang, X.; Huang, S. A New Formal Synthetic Route to Entecavir. Synlett 2019, 30, 748-752.

45. Braga, A.L.; Paixão, M.W.; Lüdtke, D.S.; Silveira, C.C.; Rodrigues, O.E.D. Synthesis of new chiral aliphatic amino diselenides and their application as catalysts for the enantioselective addition of diethylzinc to aldehydes. Org. Lett. 2003, 5, 2635-2638. [CrossRef]

46. Tanini, D.; Ricci, L.; Capperucci, A. Rongalite-Promoted on Water Synthesis of Functionalised Tellurides and Ditellurides. Adv. Synth. Catal. 2020, 362, 1323-1332. [CrossRef]

47. Tanini, D.; Capperucci, A.; Degl'Innocenti, A. Bis-(trimethylsilyl)selenide in the Selective Synthesis of $\beta$-Hydroxy, $\beta$-Mercapto, and $\beta$-Amino Diorganyl Diselenides and Selenides Through Ring Opening of Strained Heterocycles. Eur. J. Org. Chem. 2015, 357-369. [CrossRef]

48. Detty, M.R.; Seidler, M.D. Bis (trialkylsilyl) chalcogenides. 1. Preparation and reduction of group VIA oxides. J. Org. Chem. 1982, 47, 1354-1356. [CrossRef]

49. Tanini, D.; Grechi, A.; Dei, S.; Teodori, E.; Capperucci, A. An easy one-step procedure for the synthesis of novel $\beta$-functionalised tellurides. Tetrahedron 2017, 73, 5646-5653. [CrossRef]

50. Tanini, D.; Tiberi, C.; Gellini, C.; Salvi, P.R.; Capperucci, A. A Straightforward access to stable $\beta$-functionalized alkyl selenols. Adv. Synth. Catal. 2018, 360, 3367-3375. [CrossRef]

51. Tanini, D.; Borgogni, C.; Capperucci, A. Mild and selective silicon-mediated access to enantioenriched 1,2-mercaptoamines and $\beta$-amino arylchalcogenides. New J. Chem. 2019, 43, 6388-6393. [CrossRef]

52. Tanini, D.; Scarpelli, S.; Ermini, E.; Capperucci, A. Seleno-Michael reaction of stable functionalised alkyl selenols: A versatile tool for the synthesis of acyclic and cyclic unsymmetrical alkyl and vinyl selenides. Adv. Synth. Catal. 2019, 361, 2337-2346. [CrossRef] 
53. Tanini, D.; D’Esopo, V.; Tatini, D.; Ambrosi, M.; Lo Nostro, P.; Capperucci, A. Selenated and Sulfurated Analogues of triacyl glycerols: Selective synthesis and structural characterization. Chem. Eur. J. 2020, 26, 2719-2725. [CrossRef]

54. Ollivier, C.; Renaud, P. Organoboranes as a Source of Radicals. Chem. Rev. 2001, 101, 3415-3434. [CrossRef] [PubMed]

55. Ryohei Uematsu, R.; Saka, C.; Sumiya, Y.; Ichino, T.; Taketsugu, T.; Maeda, S. An autocatalytic cycle in autoxidation of triethylborane. Chem. Commun. 2017, 53, 7302-7305. [CrossRef] [PubMed]

56. Russell, G.A.; Tashtoush, H. Free-radical chain-substitution reactions of alkylmercury halides. J. Am. Chem. Soc. 1983, 105, 1398-1399. [CrossRef]

57. Abe, T.; Aso, Y.; Otsuro, T.; Ogura, F. Oxygen-Induced Transmetalation of Organoboranes with Diphenyl Ditelluride. Chem. Lett. 1990, 19, 1671-1674. [CrossRef]

58. Gladysz, J.A.; Hornby, J.L.; Garbe, J.E. A Convenient One-Flask Synthesis of Dialkyl Selenides and Diselenides via Lithium Triethylborohydride Reduction of $\mathrm{Se}_{x}$. J. Org. Chem. 1978, 43, 1204-1208. [CrossRef]

59. Krenske, E.H.; Pryor, W.; Houk, K.N. Mechanism of $\mathrm{S}_{\mathrm{H}} 2$ Reactions of Disulfides: Frontside vs Backside, Stepwise vs Concerted. J. Org. Chem. 2009, 74, 5356-5360. [CrossRef]

60. Wu, Y.-W.; Huang, S.-H.; Tseng, T.-F.; Yang, J.-F. The Mechanism Study of Free Radical $\mathrm{S}_{\mathrm{H}} 2^{\prime}$ Reactions by Leaving Group Effect and Secondary $\alpha$-Deuterium Kinetic Isotope Effect. J. Chin. Chem. Soc. 2004, 51, 1005-1011. [CrossRef]

61. If regenerated, ditellurides 3 reasonably undergoes transmetalation with ethyl radicals affording $\beta$-hydroxy-alkyl-ethyl-tellurides 2 and radicals 8 , following the proposed mechanism reported in the Scheme 3 .

(C) 2020 by the authors. Licensee MDPI, Basel, Switzerland. This article is an open access article distributed under the terms and conditions of the Creative Commons Attribution (CC BY) license (http://creativecommons.org/licenses/by/4.0/). 